\title{
VALIDITY OF SERUM LEUKOTRIENE B4 AS A PREDICTIVE MARKER OF DECOMPENSATED LIVER CIRRHOSIS IN CHRONIC HCV PATIENTS
}

Ayman El-Shayeb ${ }^{1}$, Sawsan El-Mallah ${ }^{1}$, Akram Deghady ${ }^{2}$, Doaa Elwazzan ${ }^{1}$, Samar El-Hewely ${ }^{1}$

1-Department of Tropical Medicine, 2-Department of Clinical Pathology, Faculty of Medicine, University of Alexandria.

\section{Introduction}

Chronic HCV infection is often asymptomatic and ultimately leads to cirrhosis. Liver cirrhosis is divided into two stages; compensated stage and another advanced stage which includes both decompensated cirrhosis and acute-on-chronic liver failure. The immune system is of major importance in cirrhosis pathophysiology. Sustained bacterial translocation from intestine to systemic circulation causes a chronic systemic inflammatory syndrome. Leukotriene B4 (LTB4) is a pro-inflammatory compound that was found in lots of inflammatory and allergic diseases and levels correlate with disease activity in some of these. However LTB4 role in decompensated cirrhosis hasn't been studied in depth.

\section{Aim of the work}

The aim of the study was to assess the value of LTB4 as a predictive marker of The aim of the studed cirrosis and to evaluate its relation to disease progression and complications

\section{Methods}

The current study was conducted on 80 candidates in Alexandria main university hospital, Tropical medicine Department, they were categorized into three groups, group I $(n=30)$ compensated cirrhotic patients, group II $(n=30)$ decompensated cirrhotic patients and group III $(n=20)$ apparently healthy individuals. Serum LTB4 was measured by ELISA.

\section{Results}

LTB4 showed statistically significant higher values in decompensated group than the compensated group $(p=0.007)$ and the control group $(p=0.002)$. However there was compensated group $(p=0.007)$ and the control group $(p=0.002)$. However there was
no statistically significant difference between the compensated group and the no statistically significant difference between the compensated group and the
controls $(p=0.510)$. Results showed that LTB4 cut off value to discriminate controls $(p=0.510)$. Results showed that LTB4 cut off value to discriminate
compensated cirrhosis from decompensated cirrhosis was $>16.2 \mathrm{ng} / \mathrm{L}$ with sensitivity of $93.33 \%$ and specificity of $43.33 \%$.LTB4 correlated positively with Child Pugh score $(p=0.003)$. Moreover, it correlated positively with MELD-Na score $(p=0.012)$.
Serum sodium was statistically lower in group II than group I $(\mathrm{p}=0.001)$. There was statistically significant correlation between serum level of sodium and LTB4 where $(p=0.040)$. LTB4 showed higher values in patients with lower sodium levels.

Serum CRP was statistically higher in group II than group I $(\mathrm{p}=0.001)$. There was statistically significant positive correlation between CRP and LTB4 $(p<0.006)$

\begin{tabular}{|c|c|c|c|c|}
\hline & Group I & Group II & Group III & $P$ value \\
\hline \multicolumn{5}{|l|}{$\begin{array}{c}\text { Total Bilirubin } \\
\text { (mg/dl) }\end{array}$} \\
\hline Min. - Max. & $0.20-1.40$ & $0.50-9.0$ & $0.80-1.20$ & $<0.001^{*}<$ \\
\hline Serum albumin ( $g / d l)$ & & & & \\
\hline Min. - Max. & $3.50-4.30$ & $1.60-3.0$ & $4.0-5.50$ & $<0.001^{*}$ \\
\hline INR & & & & \\
\hline Min. - Max. & $0.80-1.50$ & $1.10-2.50$ & $0.90-1.40$ & $<0.001^{*}$ \\
\hline $\begin{array}{c}\text { CRP } \\
\text { Min. - Max. }\end{array}$ & $10.0-18.0$ & $24.0-50.0$ & $1.0-5.0$ & $<0.001^{*}$ \\
\hline $\begin{array}{c}\text { Child-Pugh } \\
\text { Classification } \\
\text { A } \\
\text { B } \\
\text { C }\end{array}$ & $\begin{array}{c}30 \\
0 \\
0\end{array}$ & $\begin{array}{c}0 \\
15 \\
15\end{array}$ & NA & $<0.001^{*}$ \\
\hline $\begin{array}{l}\text { MELD/Na Score } \\
\text { Min-Max }\end{array}$ & $6.0-18.0$ & $10.0-30.0$ & NA & $<0.001^{*}$ \\
\hline $\begin{array}{c}\text { Serum LeukotrieneB4 } \\
(\text { ng/L) } \\
\text { Min. - Max } \\
\text { Mean } \pm \text { SD }\end{array}$ & $\begin{array}{l}9.11-58.73 \\
21.12 \pm 11.0\end{array}$ & $\begin{array}{l}13.62-346.1 \\
47.34 \pm 65.18\end{array}$ & $\begin{array}{c}6.21-47.45 \\
19.83 \pm 13.17\end{array}$ & $0.003^{*}$ \\
\hline
\end{tabular}

Table : Comparison between the three studied groups according to different parameters.
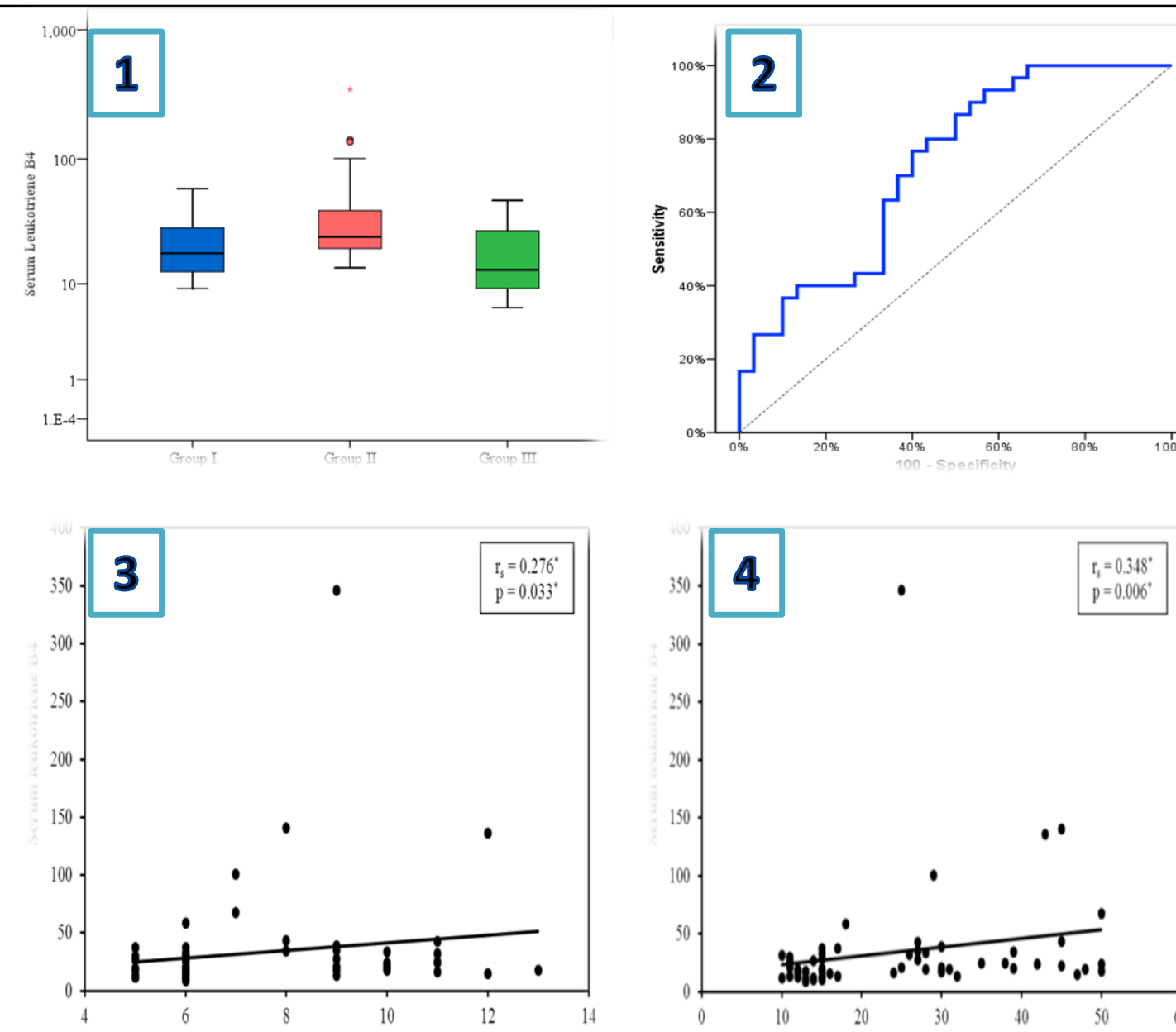

Figure (1): Comparison between the three studied groups ( $\mathrm{n}=80$ ) according to Serum LTB4. Figure (2):ROC curve for LTB4 to discriminate compensated cirrhosis patients $(\mathrm{n}=30)$ from decompensated cirrhosis patients $(\mathrm{n}=30)$

Figure (3): Correlation between LTB4 and Child Score in cirrhotic patients $(\mathrm{n}=60)$. Figure (4): Correlation between serum leukotriene B4 and CRP in total cases $(n=60)$

\section{Conclusion}

Serum LTB4 could be used as a sensitive biomarker of decompensation in cirrhotic patients. Furthermore, the significant correlation of Serum LTB4 with Child-Pugh class, MELD/Na score and CRP could suggest that it can be used as a tool for predicting the clinical outcomes of patients with liver cirrhosis and prioritize listing for liver transplantation.

$$
\begin{gathered}
\text { 20190Alexandria Faculty of Medicine } \\
\text { CC-BY-NC }
\end{gathered}
$$

MECUTYOR 